\title{
Developing English Learning Model Project Based Content And Language Integrated Learning (CLIL) For English At University Level In Indonesia
}

\author{
Drs. Huzairin, M.Pd \\ Drs. Sudirman, M.Pd
}

Drs. Basturi Hasan, M.Pd

\begin{abstract}
ABSTRAK
This study explores project based content language integrated learning (CLIL) executed at a higher education insitution in Lampung Indonesi. The research was proposed based on a mixture of the principle of language integrated learning (CLIL) and the principle of project based learning. The design was implemented for the teaching of English as a compulsory subject at Istitute of Technology Sumatera. Quantitative data was obtained from the teaching before and after CLIL model application. While the qualitative data was obtained from the output of language produced by students during the learning process took place. The results showed that project based CLIL English language course at the Istitute of Technology Sumatera could work effectively.
\end{abstract}

Key words: content language integrated learning (CLIL), project based, biology, history and economic study programs

\section{Background}

\section{INTRODUCTION}

This research is undertaken as a follow up of the previous research (Huzairin, dkk 2017). On the previous sudy the reseach was undertaken at undergraduate program of the Faculty of Teacing and Education the Univerusty Lampung. However, since the odd semester 2017 English has been a non compulsory subect for students at the university. Then study was moved to the Institute of Technology of Sumatera (ITERA) Bandar Lampung). The shifting of research site is basically practical. There is a similarity in the instructors, programs, and time allocation for teaching English both in the University of Lampung and in the Institute of Technology of Sumatera (ITERA) Bandar Lampung).

Englsh is a compulsory subject for students of higher education institutions. There maight be differece from one institution to another. The objectives of teaching English might be different for one institution to another. The differences are from one intitution to another, or from one deparetment to others.

In general, the aims of English teaching are to give students additional skills to communcate in the language so that the students can use it to communicate both orally and written. The topics of analysis were focused on language skilles: listening, speaking, reading and writing. they include analysis on vocabulary, diction, and structure in relation to the use in the community.

As stated in the previous studies (Huzairin, 2017, 2018) that the needs to master English in the future has become a big challenge for higher educationaj institutions as an institution to 
produce workers. If we wish to win global competition, higher educarion institutions must equip its graduates with the ability to communicating in English adequately.

Furthermore, for students having the ability in English will be helpfull to assist them in accomplishing their study tasks particularly in reading books written in English. Therefore, in order to answer all challenges above, there need to be upgrading in the teaching of English for non-English department students by using the most approriate planning of teaching approach. One of the ways is by placing the needs to learn as a central issue in the lesson plan. This is in accordance with English for Specific Purposes ESP in which the learners and their needs become the main consideration in determining the most effective and efficient learning direction (Hutchinson \& Waters, 1987; Robinson, 1991). The main target of such an approach is to assist the learners in order to master English in a short time with high appropriacy in accordance with field of respected study

The problems arise were the limitation of time for classroom face to face in class meeting in the classroom causes the class meeting become less effetive for the class with different English ability. In higher education system whch require active learning, the English instructors often find difficulties to deal with students whose English competence below the average among peers. In fact, English lecturers ofen find difficulties in assisting students with below average capabilies. In fact the target for teaching English at university level is high enough, i.e to enable students to possess adequate capabilities to master English so that they are able to to write in academic Engish as an international language.

One of the attempts to fulfill students' learning needs is by optimizing all potensials available. For instance, by making use of internet to gather learning material based on the field of studies. One o the steps taken was to develop

Content Language Integrated Learning (CLIL) learning model i.e by integrating lerarning different subjects with the ability to communicate in English. CLIL is the development of Englsh for Specific Purposes (ESP), which facuses on the learning of English for specific objectives, for instance, for working (vocation) or for academic Purposes.

On previos research (Huzairin, 2018, 2017) the learning through CLIL approach has been succesfully improved studens'capabilities in English. Furthermore, the application of CLIL principle at higher institution level has succefully improve the students' ability in English.

\section{The research objectives}

The research aims at:

a. Showing how project based Content Language Integrated Learning influence the fluency and accuracy of students learning English at tertiary education in Bandar Lampung, Indonesia.

b. Inventerising factors that support or hindrance the application of teaching and learning of English through project based Content Language Integrated Learning

\section{FRAME OF THEORIES}

\section{Project Based Learning}

Project based learning is a model of learning organisation in the form of project. Project is a complex learning task which is based on challenging questions or problems which involve learners in desiging problem solving, decision making or other investigating tasks, involving learners study individually for a limited time in order to produce realistic products (Jones, Rasmussen, \& Moffitt, 1997; Thomas, Mergendoller, \& Michaelson,1999).Stoller (2006) defined 
learning in project bases as the learning, which has the process and product target. Giving learners the right to owning some projects, lasted in quite longer time (for several weeks or months, to integrate skills, to develop students' comprehensibilty toward a topic through the integration of language with other learning subjects, collaborating with other students or self work, assigning new roles for students or lecturers, making the students produced high quality products.

Project based learning is a learning method using problems as the first step in collecting and integrating new knowledge based on experiences in real activities. Procect based learning is designed for the use in complex problems needed by students for investigation and comprehensibility.

Project base learning has the fllowing characteristics:

Pembelajaran Berbasis Proyek memiliki karakteristik sebagai berikut:

1. Students make a dacision on a freme work;

2. There should be problem or challenges directed to the students;

3. Students design a process to determine a decision on the problm or challenge

4. Students are responsible collaboratively to access and manage information in order to solve problems.

5. Evaluation process is done continuously.

6. Students make reflection contnuously

7. The end product of leraning activities will be evaluated qualitatively;

8. Learning situation is full tolerated toward mistakes and changes.

In its application, project base learning model have syntax (steps) specific that disinguish it from other learning models such as discovery learning model) and (problem based learning model). The steps are: (1) determining basic question, (2) desiging the project; (3) Arranging schedule; (4) momitoring the progree of the project; (5) Evaluating results; (6) Evaluating experiences.

Project base learning model always starts by finding the basic question, which later will be used as the basis for assigning students the project they should accomplieh. Of course the topic used should relate to the teal job. The next step is by the aids from the lecturers, groups of students are desiging activities that will be done in teheir respected teams. The bigger the students' involvement in contributing their ideas, the bigger stedents' sense of belonging toward the project. Next, students and lecturers determne the time limit to accomplieh the project.

The advanages and disadvantages of project based learning are

\section{The advantages of project based learning}

a. Increasing studets' learning motivation, supporting their ability to deal with important job, and their job being appreciated.

b. Improving problem solving ability

c. Making students be more active and able to accomplish with more complex job.

d. Increasing collaboration.

e. Pushing students to develop and practice their communication ability.

f. Improving students' ability in managing resources.

g. Providing experiences for students in studying and practicing in project management, predicting time and other recources such as equipment to accomplish the project. 
h. Providing learning experiences involving students in a complex job similar to their job in the real world.

i. Involving students to learn to ger information and show their capabilities that can be applied in the real world

j. Creating more enjoyable learnig experiences so that students enjoy learning situation..

\section{The weakness of Project based learning}

a. It needs long time to deal with problems

b. It needs big expenditures

c. Many instructors feel comfortable with traditional classes where the instrutors hold leading roles in the classroom.

d. A lot of equipments that shold be prepared

e. Students who have weaknesses in experiment and collecting information will get difficulties.

f. Sudentws who have less experience in group work will face problems.

g. Students will face problems when they are exposed to a topic to be deaalt with. In order to deal with weaknesses in project based learnig an educator should be able to deal with it by facilitating students to deal with the problems, limiting time to deal with the problems, mimimalising and providing equipments available in the project area, limiting time to accomplish with the project, minimising and providing simple tools available, choosing reachable research locations, creating comfortable learnig situations comfortable for students to learn.

Project base learning also requires students learn to develop skills such as collaboaration and refelction. According to research project base learning helps students improve their social skills, mimimizing absentee, and improve the discipline problem.

Prjoect based learning also increases students' enthusiasm of wha they are learning. When the students have high enthusiasm on what they learn, they become more involved in learning the subject and expand their interest toward other subjects. Ethusiasm students toward defending what they learn, not to forget what they have learned.

Based on the exlanation above, the followings are activities that sholod be accomplished:

a. Determining project. In this phase students determine the theme/topic of the project based on the assignmen given by the lacturer'. The students are given to opportunity to choose/determine the projects done in group or personal personal choice.

b.Designing the steps to accomplish the project. Students design steps to accomplish with the project from the beginning to the end of the project. The design of the project contain rules in executing project, selection of activities that can support the project, the integration of project accomplishment planning, the planning of resources, materials, and equipments thah can support the projectm and coordinatios among members.

c. Setting up schecules for project. Students, unders supervision from lecturers arrange the schedules of the project.

\section{d. Project execution under the lecturers' supervision.}

This step is the implementation of project planning under lecturers' supervision. This step is the implementation of project planning made. Activities that can be done in the project are: a) 
reading, b) researhing, c) observing d) interviewing, e) recording, f) producing art, g) visiting project object, or h) accessing internet. The lecturers are responsible to implement the project, starting from the planning to finishing the project. In monitoring activities, lecturers made rubric than can record students' activities in accomplishing project. e. Report writing and reporting/presentation and publication The results of the project in form of products whether in the form of written report, art, or technology products are presented and/or published to other lecturers or students in form of exhibition. f. Evaluation on the process and products. Students and lecturers do some reflections on the activities and results of the project.

Reflection process on project jobs can be accomplished individually and in groups. At the evaluation stage, the students are given the opportunity to expese their experiences during the accomplishment of the project. This is followed by dicussion to improve the accomplshment of the project. Feed back session on the prosess and product are aslo dealt with during thie process.

\section{Evaluation in Project Based Learning model}

Because project base learning can give the learning product in the form of (knowledge), skill or psychmotoric and attitude or affective, then the evaluation is given on those domains. Evlauation format can be test or non test. It is suggested that the evaluation of project base learning give more priority to students' ability to manage their activities to accomplish with their chosen project, the relevance of the project with the topic of the learning so that they can manage the originality of the project.

2. Students need to be given explanation about deep way of thinking, systematic, radical and universal about their field study.

3. Students develop the thinking realistically by providing a lot of examples.

4. Students must be assigned learnig tasks that can stimulate their thinking realistically and realized it in the form of writing.

5. Students musr be stimulated to ask more, because it can stimulate them to think more.

\section{Research Design}

\section{RESEARCH METHOD}

This research implemented Developmental Research. The research was oriented toward product development in which the developmental process was described in detail and the products are finally evaluated. In the teaching of English the developmental research is applied over and over from the design and examination toward learng material products. (Gravemeijer, 1999). The output of the research is high quality products theoreticaaly, methologica procedures and empirically.

Research and development is a strategy to develop effective educational products . The educational research and development is an industrty with model developmental in which researh inventions are used to develop new productcs and procedures which is systematically tried out, evaluated, and revised untill effective criteria or quality reach particular standard (Gall, Gall and Borg, 2003). The steps and processes of development refers to research and development which consist of studying research inventions related to products being developed, developing products based on scientifiic findings, try out of designs, revising the products to improve the weaknesses on try out phase. This is because, according to Borg (1979), the intention of research and development is to bridge the gaps that are often found between educational research and educational practice.

The main steps in doing educational research and development are:

(1). Literature stydy 
(2). Planning

(3). Developing early product model (theoretical)

(4). Field test of early model

(5). Early product test to produce main products

(6). Field test of main product

(7) Revision of main product to empirical model

(8). Field test of operational products

(9). Revision of opersional products to produce end products.

(10). Disemination and distribution of end products (Gall and Borg in Distrik et al, 2009).

\section{Complete procedures of evaluation:}

Pre test

Pretesst is undertaken to be the basic for students groping. The grouping is done separating students with good capabilty and non good capabilitis based their test. The test material is self introduction in English.

Instruction: Every one is asked to inroduce him/herself in front of the class

Material coverage: Name, Address, place/date of birth, school, number of siblings,hobbies...

Recording

1.1.1 Every student is recorded

1.1.2 Scoring:: pertormance: self introduction is scored based on the following factor: fluency, prununcation, intonation, grammar, vocabulary.

\section{Grouping}

After each student is scored, their scores is categorized as good or not good.

\section{Input Processing}

1. Lecturer review sentences and tenses that underlie a text: some reviews on the types of sentence based on the structure; simple, compound or complex, active and passive sentences, verbal and nominal, positive, negative, and interrogative in various tenses

2. Reviw text types:: narrative, descriptive, argumentative, descriptive, argumentative, and academic texts.

The steps that should be done:

One class consists of 40-80 students

Students are asked to project in groups.

The Project is done in groups

Determining reading materials used.

\section{RESULTS AND ANALYSIS}

Content Language Integrated Learning (CLIL) is implemened in several study programs at Institut Teknologi Sumatera as the realisation of 2 credit subject. The subject aims at providing students with the ability to master English with subskills of listening, speaking, reading and writing in English. These skills are expected to able to equip students develop their academic potentials. Formally, English as subject, is taught in 100 minute of learning face to face, structured learnig activities, and self study for 100 minutes. The number of meeting time is 16 meetings in one semester. 
For the English subject given for the odd semester 2017/2018, the implementation was devided in to two term: before the mid semester term consists of 8 meetings. Another 8 meetings were implemented for the second term of the session.

In each term, content language integrated learning on project base is organised with different emphasis. To evaluate the students were given tasks related to language skills: listening, reading, speaking, and writing, to complete the langage instruction by the lecturer.

The following table illustrates the descriptive statistcs of the learning results of four lerning results: lab work tasks, speaking task, writing task, and language analysis tasks

Tabel 4.1. Deskriptive statistics of learning results

\begin{tabular}{|l|c|c|c|c|c|}
\hline & $\mathrm{N}$ & Minimum & Maximum & Mean & Std. Deviation \\
\hline Labwork & 128 & 43,00 & 80,00 & 67,9063 & 8,21306 \\
Writing & 128 & 52,00 & 85,00 & 71,3646 & 8,28965 \\
Speak & 128 & 41,67 & 78,67 & 66,4489 & 8,26424 \\
Grammar & 128 & 41,00 & 80,00 & 65,7396 & 8,82967 \\
Valid N & 128 & & & & \\
(listwise) & & & & & \\
\hline
\end{tabular}

Table 4,1 shows that for lab work tasks the lowest point was 43 , the highest point was 80 , and the average score was $67,90 \mathrm{sd}=8,21$. For writing task, the lowesr score was 52 , the hughest score was 85 , the mean score was 71,36 , sd $=8,28$. For speaking task, the lowest point was 41,67 , the highest point was 78,76, znd the average score was $66,44 \mathrm{sd}=8,26$. For grammar task the lowesr score was 41 , the highest score was 80 , the maen score $65,73 \mathrm{sd}=8,83$.

\section{Analysis on lab work learning task}

To answer research question: Is there any significant inluence of students' streaming on the learning tasks to students' achievement Mutivariate Analysis of Variance (MANOVA) was used. The following table illustrates the deskriptive statistics of the influence of lab work task on students' achievement.

Table 4.2 Deskriptive statistics of students achievement on lab work

\begin{tabular}{|c|c|c|c|c|c|c|}
\hline & $\mathrm{N}$ & Mean & Std. Deviation & Std. Error & Minimum & Maximum \\
\hline 1,00 & 28 & 69,2500 & 8,09858 & 1,65312 & 50,00 & 80,00 \\
2,00 & 28 & 68,7917 & 9,39926 & 1,91862 & 43,00 & 80,00 \\
3,00 & 28 & 68,3333 & 7,39957 & 1,51043 & 52,00 & 80,00 \\
4,00 & 28 & 65,2500 & 7,72489 & 1,57684 & 48,00 & 76,00 \\
Total & 128 & 67,9063 & 8,21306 &, 83824 & 43,00 & 80,00 \\
\hline
\end{tabular}

In order to answer research question: Is there any significant infuence of students' division on four learning tasks of English learning at Institut Teknologi Sumatera, a parametric statistical evaluation Analsis of Variance was undertaken and the results are presented in the following in tabel 4.3.

Tabel 4.3 ANOVA result on students' qualification of lab work learning

\begin{tabular}{|l|c|c|c|c|c|}
\hline & Sum of Squares & Df & Mean Square & F & Sig. \\
\hline Between & 235,865 & 3 & 78,622 & 1,172 &, 325 \\
Groups & 6172,292 & 123 & 67,090 & & \\
Within Groups & 6408,156 & 125 & & & \\
Total & & & & \\
\hline
\end{tabular}


The ANOVA test for students' division on lab work study shows the F value of 1,172 . This means that there is no significent difference beween students' score on lab work and the students' division. However, there us a relative difference between tne students' achievement in lab work and students' division. This can bee seen in the following plots.

Figure 4.1 mean plot lab work score based on students' score

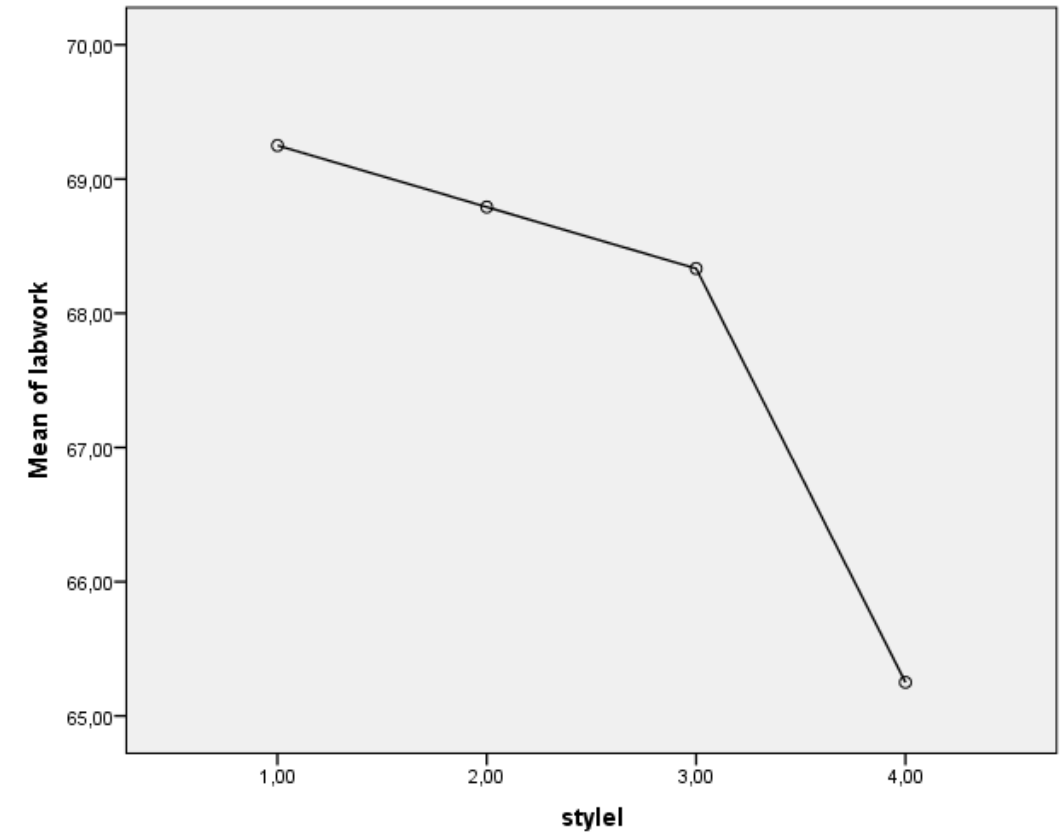

Note: $1=$ upper class $1 \quad 2=$ upper class 2

3 = lower class $1 \quad 4=$ lower

Based on the mean plot students' score on labwork, the highest score was gained by students in upper class 1 category, followed by students with upper class 2 category. The lowest scores were gained by student with lower class categorty 1 and 2. This means that for lab work actvities, there is a congruenncy between students' category and their learning achievements.

\section{Analysis of speaking tasks.}

In order to answer the question is there any inflence of categorizing students into categories toward stedents' achievement of speaking, Mutivariate Analysis of Variance (MANOVA) was applied. The following table shows descriptive statistics of speaking task into four types af learning achievement.

Table 4. Deskriptive statistics os students' speaking achievement

\begin{tabular}{|l|c|c|c|c|c|c|}
\hline & $\mathrm{N}$ & Mean & Std. Deviation & Std. Error & Minimum & Maximum \\
\hline 1,00 & 28 & 67,7778 & 8,76679 & 1,78951 & 48,67 & 78,00 \\
2,00 & 28 & 67,1389 & 9,73113 & 1,98636 & 41,67 & 78,67 \\
3,00 & 28 & 66,2681 & 6,40604 & 1,30763 & 51,67 & 76,00 \\
4,00 & 28 & 64,6110 & 7,97569 & 1,62803 & 44,33 & 77,33 \\
Total & 128 & 66,4489 & 8,26424 &, 84347 & 41,67 & 78,67 \\
\hline
\end{tabular}

Note: $1=$ upper class $1 \quad 2=$ upper class 2

3 = lower class $1 \quad 4=$ lower 
In order to answer the question: Is there any significant influence of student classification on the speaking learning task at Institut Teknologi Samatera Lampung statistical testing Analysis of Variance was applied with the result is illiustrated in fig.4.5.

Tabel 4.5 The ANOVA of students' achievement and learnng task of speaking

\begin{tabular}{|l|c|c|c|c|c|}
\hline & Sum of Squares & Df & Mean Square & F & Sig. \\
\hline Between & 135,664 & 3 & 45,221 &, 655 & \multirow{2}{*}{, 582} \\
Groups & 6352,612 & 125 & 69,050 & & \\
Within Groups & 6488,276 & 123 & & & \\
Total & & & & \\
\hline
\end{tabular}

The result of ANOVA test on the influence of learning style categorization toward speaking shows the F 0,655. This means there is no sinificent difference between the students' score in lab work and students' calssification. However there is still relative difference between the students' achievement in lab work and the students' qualification. This can be seen from the following mean plot.

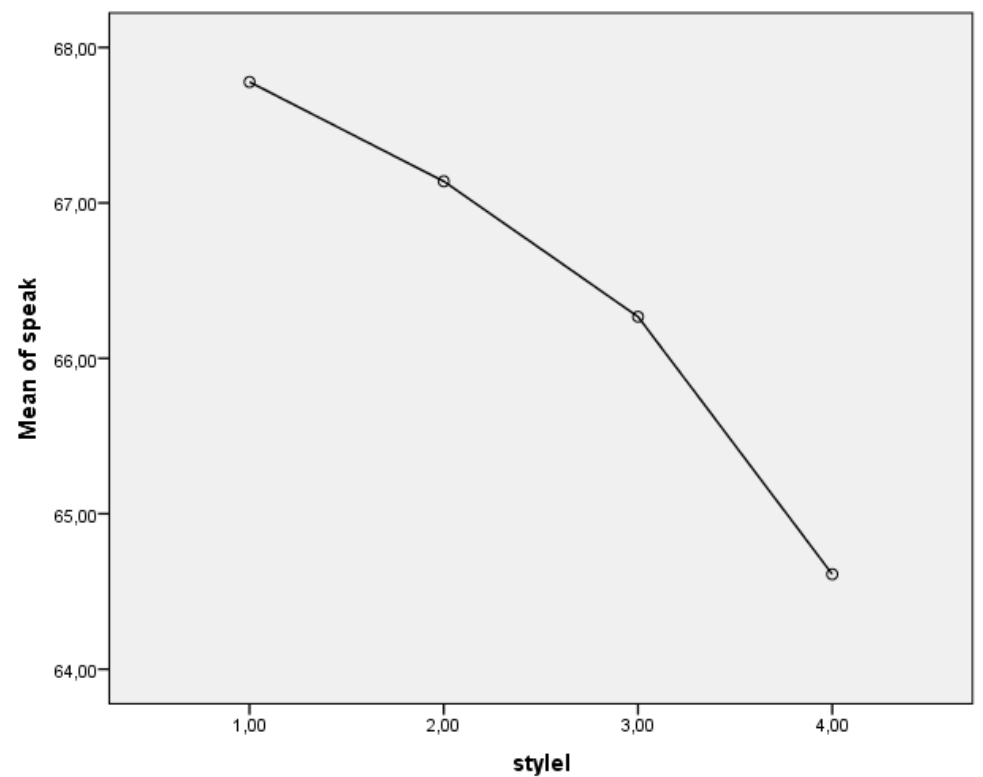

$1=$ upper class $1 \quad 2=$ upper class 2

$3=$ lower class $1 \quad 4=$ lower

Based on mean plot of students' lab work achievement, it can be seen that the highest score was gained by the students in category upper class 1 followed by students in upper class 2 . The lowest score was gained by students in lower class 2 category. This means that there is a congruency between learnig category and learning task.

\section{Analysis of writing task}

In order to answer research question is there any significant influence of learning categories toward the achievement of writing at Institut Teknologi Sumatera, statistical testing Analysis of Variance was undertaken. The result of the calculation is presented in table 4.6

Tabel 4.6 ANOVA on qualification on writing task

\begin{tabular}{|c|c|c|c|c|c|c|}
\hline & $\mathrm{N}$ & Mean & Std. Deviation & Std. Error & Minimum & Maximum \\
\hline 1,00 & 28 & 71,5833 & 9,30599 & 1,89958 & 53,00 & 85,00 \\
2,00 & 28 & 75,3750 & 5,80714 & 1,18538 & 62,00 & 85,00
\end{tabular}




\begin{tabular}{|l|c|c|c|c|c|c|}
3,00 & 28 & 70,5417 & 7,66686 & 1,56499 & 52,00 & 85,00 \\
4,00 & 28 & 67,9583 & 8,66517 & 1,76877 & 52,00 & 80,00 \\
Total & 128 & 71,3646 & 8,28965 &, 84606 & 52,00 & 85,00 \\
\hline
\end{tabular}

In order to asnswer research question is there any significant inflence of student qualification toward writing achievement of English at Institut Teknologi Sumatera, a statustical test Analysis of Variance was organized with the following result

Tabel 4.7 ANOVA on kualifikation and writing task

\begin{tabular}{|l|c|c|c|c|c|}
\hline & Sum of Squares & Df & Mean Square & F & Sig. \\
\hline Between & 681,865 & 3 & 227,288 & 3,577 &, 017 \\
Groups & 5846,375 & 123 & 63,548 & & \\
Within Groups & 6528,240 & 125 & & & \\
Total & & & & \\
\hline
\end{tabular}

The ANOVA of the inluence of student classification on speaking tasks shows the $\mathrm{F}$ value of 3,577. This means that there is a significant difference in students score in writing and differene classification at significant level 0,05. This can be seen from the followong mean plot . Based on the mean plot of students' writing scores, it can be seen that the highest score was achieved by students with upper class1 category. The lowest score was gained by students with lower class category. This means that for speaking task there was an inconrueny between learning category and learning task designed for such learning task. It was found that students with upper class got the highest score in writing.

\section{Analysis learnig tasks on grammar analysis}

In order to answer the question is there any infuence of categorization of learning task on of English grammar analysis at the Institute of Technology Sumatera, Statistical tesing Analysis of Variance was conducted with the following resuls

Tabel 4.9 The results of ANOVA on the qualification and grammar learning,

\begin{tabular}{|l|c|c|c|c|c|c|}
\hline & $\mathrm{N}$ & Mean & Std. Deviation & Std. Error & Minimum & Maximum \\
\hline 1,00 & 28 & 66,5417 & 9,40850 & 1,92050 & 42,00 & 78,00 \\
2,00 & 28 & 66,0417 & 10,04546 & 2,05052 & 41,00 & 78,00 \\
3,00 & 28 & 65,9583 & 7,16561 & 1,46267 & 51,00 & 80,00 \\
4,00 & 28 & 64,4167 & 8,86575 & 1,80971 & 44,00 & 80,00 \\
Total & 128 & 65,7396 & 8,82967 &, 90117 & 41,00 & 80,00 \\
\hline
\end{tabular}

$1=$ upper class $1 \quad 2=$ upper class 2

3 = lower class $1 \quad 4=$ lower

In order to answer the question is there any influence of studets' categorization on grammar analysis at the Institute Technology Sumatera statistical analysis using Analysis of Variance was conducted with the following result:

Tabel 4.10 ANOVA categizing students and grammar analysis tasks

\begin{tabular}{|l|c|c|c|c|c|}
\hline & Sum of Squares & Df & Mean Square & F & Sig. \\
\hline Between & 60,781 & 3 & 20,260 &, 254 &, 858 \\
Groups & 7345,708 & 92 & 79,845 & & \\
Within Groups & 7406,490 & 95 & & & \\
Total & & & & \\
\hline
\end{tabular}


The ANOVA shows that the significant influence of categrizing students toward speaking assignment of $\mathrm{F}$ is 0,254 . This means there is no significant difference between students lab work and the students' categization. This can be seen from the following mean plot:
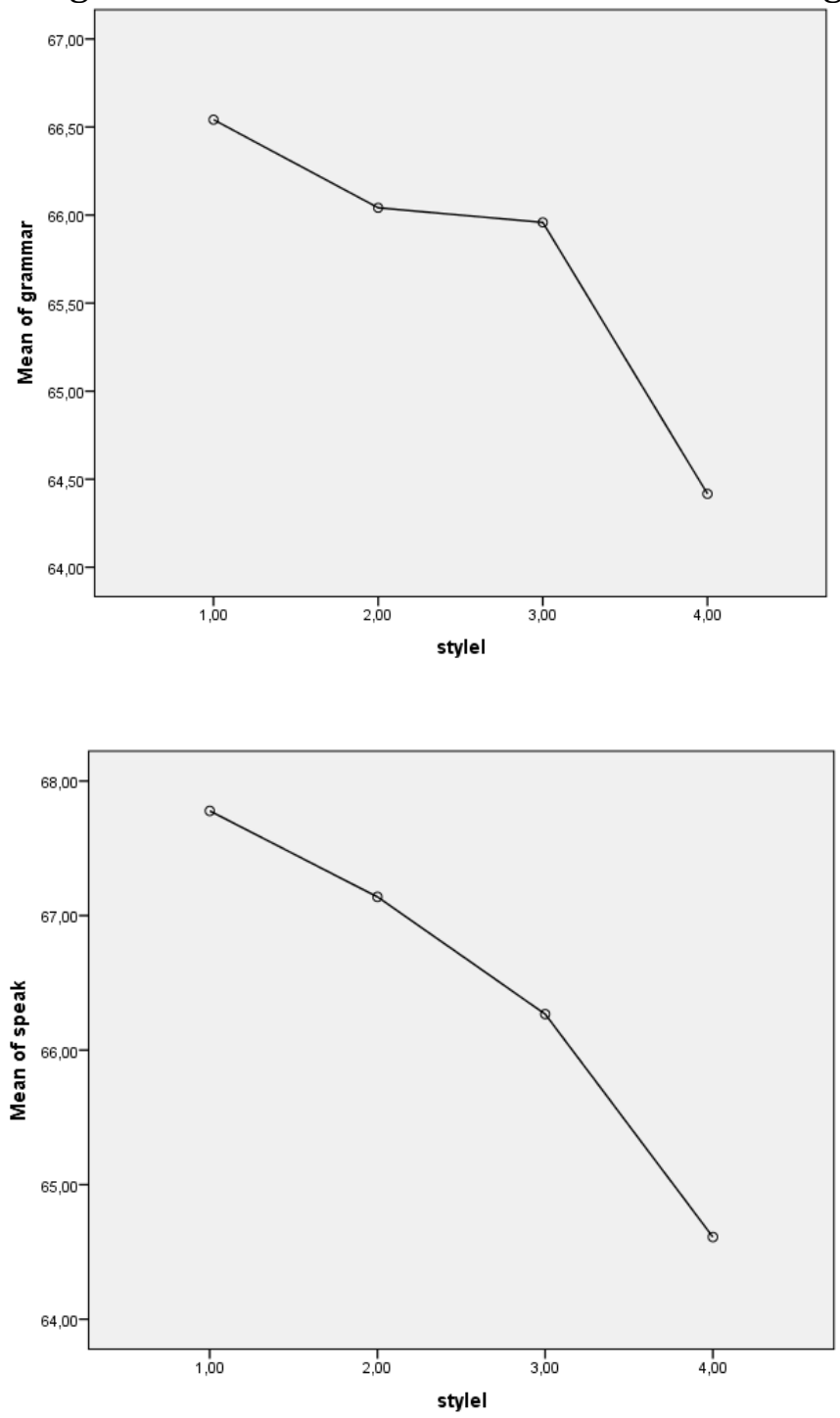

\section{ANALYSIS}

From a series of statistical analysis, it can be concluded that there is no significant inflence of different learning tasks toward the quantity and quality of speaking when involved in the interactions. This can be seen from the F count in statistical analysis in students' amount of speaking (length of time of speaking, number of turns, and C-unit) and also the $\mathrm{F}$ count for quality of speaking which cannot be categorized significant because the $\mathrm{F}$ value is not $>0,05$. However, even though there is no significant influence of different learning tasks on the quanirty and quality of students' speaking, there are still students' speaking ability designed by the researcher with the characteristics of students' achievement.

This funding supports previous study by Brown 1994 who stated that if teachers could give students a kind of assignment suitable to their capability the performance will better. If the students' learning style is suitable with insructional style, morivation, their performance and achievement will increase.

There are some important findings from the research. Among others are: procect base CLIL on English subject at Institut Teknologi Sumatera could run well. This is proven from the overall 
application of programs from the establishment of of study groups, students work in groups to accomplieh the project well. Group presentation, personal presentatation, and presonal responses activities were done in English. These are in accordance to Mangubhai (2000) who stated that immersion language learning (joining ianguage to subject matter resulted in maximum results (2000,pp 203).

Other phenomena that can be attained through this study are product oriented and process oriented learnig. Product oriented learnings are generally based on behavioristic psycological theory of Pavlov, Thorndike works, and from the study Watson and Rayner which applied Pavlov's study on psycological disturbances. Skinner's works considered as important reference in this field and its application in educational world. (Joyce, Weil, \& Calhoun, 2000: 318). In language teaching, model learning in group generally has the characteristics proposed by Krashen (1981) 'learning', such as bound in formal procedure, product/performance orientation, and squenced basd on grammar.

Teachers' role is dominant in determining learning goals and procedures. Thi role is dominant in drill and substitution activities common in this approach. Audiolingual Approach, is basically rooted from two parallel ideas in linguistics and psycology. In psychology field, this approach has rooted on behaviorisme and neo-behaviorisme, in linguistics this approach is rooted on structuralis and descriptive. (Hadley, 2001).

The teaching method produced from this approach were given the same name: audiolingual method, also known as Functional skills, New key information, and American Method (Benseler \& Schulz, 1980). Different from product oriented learning model, learning model in this group has rooted on ideas from social theories which emphasized on human social nature, the way humans learn social interaction, strengthening the success of academic learnning (Joyce, Weil, \& Calhoun, 2000).

In practice, these principles form the development of cooperative learning society. Assumptions that base the practice was summarised by Joyce, Weil, dan Calhoun (2000), 1) Synergy produced from cooperative arrangement produced stronger motivation than those produced by individualistic and competitive environment. Therefore, integrative social group is more than just sub part component. Hidden sense resulted in positive energy. 2) Members of cooperative group learn from each other. Every student get more helps than self effort. 3) Interactions among members produced cognitive complexity besides social complexity created intellectual activities that support learning than self learning. 4) Cooperation increases positive feeling toward others, minimising loneliness and feeling isolated, develop relations, and meningkatgiving solid view toward others. 5) Cooperations increases self image not only through increasing learning but also feeling respected and appraised by others. 6) Students could respond experiences in accomplishing tasks requiring cooperations through improvement of their cooperaiveness. In other words, the more the students are given the opportunity to cooperative. This will help them improving their social welfare. 7) Students, including elementary school students, can learn from practice to improve their cooperatve skills.

\section{Conclusions}

\section{CONCLUSIONS AND SUGGESTION}

From the description of the results of research and the analysis, it can be concluded that: a) There a significant influence of Project based Integrated Language Learning toward the fluency and accuracy of English by students at the Institute of Technology Sumatera. This was proofed by significant difference difference between students' ability before and after the application of 
Project based Integrated Language Learning. b). Students' responses toward the teaching of English through Project based Integrated Language Learning were positive. This is evidenced from the studets' responses through questuinnaire answers before and after the application of the language program.

\section{Suggestions}

Based on the results of the research, some suggestions are proposed:

Teaching English at higher education level are suggested to accommodate students' needs toward better quality of English teaching at higher education institution. Teaching and learning activities proposed should be able to accommodate students' need of learning English at hegher aducation institutons.

\section{References}

Anderson, L. W., \& Krathwohl, D.R. (Eds). (2001). A taxonomy for learning, teaching,and assessing: A revision of Bloom's taxonomy of educational objectives. New York:Longman.

Bentley, K. (2010). The TKT course CLIL module. Cambridge: Cambridge University Press.

Coyle, D. (2007). Content and language integrated learning: Towards a connected research agenda for CLIL pedagogies. The International Journal of Bilingual Education and Bilingualism, 10, 543-562.

Coyle, D., Hood, P., \& Marsh, D. (2010). CLIL: Content and language integrated learning. Cambridge: Cambridge University Press.

Johnson, D. W., Johnson, R. T., \& Holubec, E. J. (1994). The new circles of learning:cooperation in the classroom and school. Alexandria: Association for Supervision and Curriculum.

Kagan, S. (1992). Cooperative learning. San Juan Capistrano, California: Kagan Cooperative Learning.

Lorenzo, F., Casal, S. and Moore, P. (2010). The effects of content and language integrated learning in European education: Key Findings from the Andalusian Bilingual Section. Evaluation Project. Applied Linguistics, 31, 418442.

Lasagabaster, D. (2008). Foreign language competence in content and language integrated courses. The Open Applied Linguistics Journal, 1, 31-42.

Lasagabaster, D. (2011). English achievement and student motivation in CLIL and EFL settings. Innovation in Language Learning and Teaching 5(1), 3-18.

Jones, B. F., Rasmussen, C. M., \& Moffitt, M. C. (1997). Real-life problem solving.: Acollaborative approach to interdisciplinary learning. Washington, DC: American Psychological Association.

Miller, P. C. 2006. Integrating second language into project-based instruction. In project-based learning in second and foreign language education: Past, present, and future, ed. G.H. Beckett and P.C. Miller, 225-40. Greenwich, CT: Information Age

Stoller, F. 2006. Establishing a theoretical foundation for projectbased learning in second and foreign language contexts. In Projectbased second and foreign language education: Past, present, and future, ed. G.H. Beckett and P.C. Miller, 19-40. Greenwich, CT: Information Age

Thomas, J. W. \& Mergendoller, J. R. (2000). Managing project-based learning: Principles from the field. Paper presented at the Annual Meeting of the American Educational Research Association, New Orleans.

Thomas, J. W., Mergendoller, J. R., and Michaelson, A. (1999). Project-based learning: A handbook for middle and high school teachers. Novato, CA: The Buck Institute for Education.

Hadley, A. O. (2001). Teaching Language in Context Third Edition. Boston, MA: Heinle and Heinle Thomson Learning

Huzairin, et al 2017. Pengembangan Model Pembelajaran Bahasa Inggris Content And Language Integrated Learning (Clil) Berbasis Project Mata Kuliah Bahasa Inggris Di Perguruan Tinggi. Laporan Penelitian. Universitas Lampung.

Joyce, B., Weil, M. \& Calhoun, E. (2000). Models of Teaching Sixth Edition. Boston: Allyn and Bacon.

Krashen, S. D. (1981). Second language acquisition and second language learning. New York: Pergamon.

Krashen, S. D. (1982). Principles and Practices in Second Language Acquisition. Oxford: Pergamon. 
Kumaradivelu, B. (2001). Toward a Postmethod Pedagogy. TESOL Quarterly, 28, 27-48.

Robinson, R. D., McKenna, M. C., dan Wedman, J. M. (Eds.) (2000). Issues and Trends in Literacy Education Second Edition. Needham Heights, MA: Allyn and Bacon.

\section{BIODATA}

Huzairin Djahri attained his M.Pd at IKIP Malang, East Java. He has been a lecturer at the English Study Program, the faculty of teaching and education, Universitas Lampung since 1986. His subjects areas included vocabulary teaching, micro teaching, and cross cultural understanding. His area of interests comprise the teaching of vocabulary, semantics, and pragmatics

Basturi Hasan accomplished his under graduate study (S-1) at FKIP Universitas Lampung and pursued his DIP TEFL Program at the University of Sydney Australia, and attained his M.Pd at IKIP Malang, East Java. He has published books entitled "Refining Sentence Writing Skills for Professional and Academic Purposes: A Practical Application of Modern Rhetoric," and "Paragraph Writing for academic Courses: A Modern Approach." He also published several articles focusing on Errors Analysis in English and Ways to Correct Them, New Orientations in the Teaching of English as an Important New Model for the Teaching-Learning Program, TEFL Methods, Techniques, and Approaches, also Research in TEFL Skills. 